\title{
PUBLIC KNOWLEDGE, PRIVATE KNOWLEDGE: THE INTELLECTUAL CAPITAL OF ENTREPRENEURS
}

\author{
Albert Link \\ Christopher Ruhm \\ Working Paper 14797 \\ http://www.nber.org/papers/w14797 \\ NATIONAL BUREAU OF ECONOMIC RESEARCH \\ 1050 Massachusetts Avenue \\ Cambridge, MA 02138 \\ March 2009
}

The views expressed herein are those of the author(s) and do not necessarily reflect the views of the National Bureau of Economic Research.

NBER working papers are circulated for discussion and comment purposes. They have not been peerreviewed or been subject to the review by the NBER Board of Directors that accompanies official NBER publications.

(C) 2009 by Albert Link and Christopher Ruhm. All rights reserved. Short sections of text, not to exceed two paragraphs, may be quoted without explicit permission provided that full credit, including $\odot$ notice, is given to the source. 
Public Knowledge, Private Knowledge: The Intellectual Capital of Entrepreneurs

Albert Link and Christopher Ruhm

NBER Working Paper No. 14797

March 2009

JEL No. M14,O31

\begin{abstract}
This paper focuses on the innovative actions of entrepreneurs, namely their tendency to reveal the intellectual capital that results from their research efforts either in the form of public knowledge (publications) or private knowledge (patents). Using data collected by the National Research Council within the U.S. National Academies from their survey of firm's that received National Institutes of Health Phase II Small Business Innovation Research awards between 1992 and 2001, we find that entrepreneurs with academic backgrounds are more likely to publish their intellectual capital compared to entrepreneurs with business backgrounds, who are more likely to patent their intellectual capital. We also find that when universities are research partners, their presence complements the tendencies of academic entrepreneurs but does not offset those of business entrepreneurs.
\end{abstract}

\author{
Albert Link \\ Department of Economics \\ Bryan School, UNCG \\ P.O. Box 26165 \\ Greensboro, NC 27402-6165 \\ al_link@uncg.edu \\ Christopher Ruhm \\ Department of Economics \\ Bryan School, UNCG \\ P.O. Box 26165 \\ Greensboro, NC 27402-6165 \\ and NBER \\ chrisruhm@uncg.edu
}




\section{Public Knowledge, Private Knowledge: \\ The Intellectual Capital of Entrepreneurs}

\section{Introduction}

Throughout intellectual history as we know it, the entrepreneur has worn many faces and played many roles. One important role is that of innovator, and that role is most commonly associated with the writings of Joseph Schumpeter. ${ }^{1}$ For Schumpeter, the main instrument of change in his theory of economic development is the entrepreneur. The entrepreneur is the persona causa of economic growth and development. According to Schumpeter (1934, p. 78), “everyone is an entrepreneur only when he[/she] actually 'carries out new combinations'” of resources. ${ }^{2}$

Schumpeter defined innovation with reference to the production function. The production function, he said (1939, p. 62), “describes the way in which quantity of product varies if quantities of factors vary. If instead of quantities of factors, we vary the form of the function, we have an innovation.” Schumpeter (1928, p. 378) recognized that the knowledge that kindles an innovation need not be new; it may be existing knowledge that is manifested in "the successful solution of the task sui generis of putting an untried method into practice.”

In this paper we focus on two competing innovative actions by entrepreneurs, or more specifically, by entrepreneurs' firms. Both relate to the tendency of the firm to combine resources in untried ways to create new knowledge (i.e., intellectual capital) and then to either publish that knowledge or patent it. Our hypothesis is that the vocational background of a firm's founder(s) - hereafter referred to as the background of the entrepreneur(s) —influences the firm's

\footnotetext{
${ }^{1}$ The forerunner to Schumpeter was Abbé Nicholas Baudeau. Baudeau (1910) treated the agricultural entrepreneur as a risk bearer, in the manner of Cantillon (i.e., uncertainty), but he added a distinctly modern twist. He made the entrepreneur an innovator as well, one who invents and applies new techniques or ideas in order to reduce his costs and thereby raise his profit. Other writers, besides Baudeau and Schumpeter, who emphasized the theme of the entrepreneur as an innovator and leader comme aucun autre include, Bentham, Thünen, Schmoller, Sombart, and Weber. See Hébert and Link (1998, 2006, 2007, forthcoming).

2 Teece and Pisano (1994, p. 553) contend that Schumpeter "saw economic development as consisting of a process where entrepreneurs dipped into a stream of technical opportunities ostensibly made for reasons independent of particular markets and brought those innovations to market.”
} 
strategic choice to reveal its intellectual capital either as public knowledge (i.e., open source knowledge through publishing) or as private knowledge (i.e., appropriable knowledge through patenting).

In Section II, we motivate this hypothesis is greater detail, and we proffer an empirical model to test it. In Section III, we discuss a unique set of data related to the performance of small, entrepreneurial firms funded through the National Institutes of Health's (NIH’s) Small Business Innovation Research (SBIR) program, and in Section IV we report our econometric analyses of these data. Finally, in Section V, we discuss our findings in light of an environment in which entrepreneurial activity is increasing being viewed as an engine of economic growth.

\section{The Entrepreneur's Background and Innovative Outputs}

There is a rich body of literature, primarily within the management and strategy disciplines, that was pioneered by Delmar and Shane (2002) and Shane (2003), on various characteristics of entrepreneurs and the economic performance of their firms. One primary focus of that literature has been on the relationship between the entrepreneur's human capital and firm performance as quantified in terms of its survival and growth. ${ }^{3}$ Conspicuously absent from this burgeoning literature are studies relating the entrepreneur's vocational background and his firm's innovative behavior (as we have measured it) — a critical relationship when drawing implications about the social contribution of entrepreneurial firms. ${ }^{4}$ This paper provides a first step towards filling this void.

The conceptual argument that the background of the entrepreneur influences his firm's behavior is based on several strands of literature. ${ }^{5}$ Sociologists contend that individuals often imprint their beliefs and values on situations in which they have control. For example, Stinchcombe (1965) is often heralded with the general observation that the founding history of an organization (e.g., a

\footnotetext{
${ }^{3}$ For instance, see Colombo and Grilli (2005). Baron and Ensley (2006), for example, examined the relationship between background and opportunity recognition.

${ }^{4}$ See Audretsch (2009). Roper (1998), for example, studied the relationship between entrepreneurial characteristics (e.g., year of education and experience in firms with 500 or more employees) and strategic choices (e.g., entering into new markets or management changes with the organization).

${ }^{5}$ Surprisingly, these strands of literatures have not previously been woven together in a paradigmatic way to formulate testable hypotheses.
} 
firm) directly influences the present structure of that organization. ${ }^{6}$ That is, the founding history or background of the founder establishes blueprints or organizational forms that direct, to varying degrees over time, the observed behavior of the organization. This occurs because the blueprints tend to become institutionalized and the structure of the organization thus tends to remain stable.

From an economic perspective, Richardson (1972, p. 888), building on Penrose (1959), states: "The capabilities of an organisation may depend upon command of some material technology ... [and] organisations will tend to specialize in activities for which their capabilities offer some comparative advantage .... ." To the extent that the firm's capabilities are influenced, if not determined, by the founder's background, then that background should influence how the firm achieves it comparative advantage. ${ }^{7}$ Chandler (1992, p. 86), extending the arguments of Richardson, noted that "the specific nature of the firm's facilities and skills becomes the most significant factor in determining what will be done in the firm ...."

And, from a management and strategy perspective, the theoretical paradigm dominating the strategy literature is the resource based view of the firm (RBV), first introduced by Wernerfelt (1984) and subsequently refined by Barney (1991) and others. ${ }^{8}$ The RBV perspective posits that firms are bundles of heterogeneous resources and capabilities, and those resources and capabilities influence the firm's competitive strategy. ${ }^{9}$ To the extent that these bundles of heterogeneous resources and capabilities have been influenced by the entrepreneur's blueprint for the firm and attendant skills within the firm, then the entrepreneur's background is related to the firm's performance.

\footnotetext{
${ }^{6}$ Baron, Hannan, and Burton's (1999, p. 529) interpretation of Stinchcombe’s theory is that "founding conditions become imprinted on organizations and mold their subsequent development."

${ }^{7}$ Richardson was influenced by the work of Coase. According to Coase (1937, p. 393), in his seminal paper on the nature of the firm: "A firm, therefore, consists of the system of relationships which comes into existence when the direction of resources is dependent on an entrepreneur."

${ }^{8}$ The RBV framework is in contrast to the paradigm that preceded it, namely Porter's theory $(1980,1985)$ of competitive advantage. See Link and Siegel (2007) for a more in depth discussion of these paradigms.

${ }^{9}$ Barney (1991), for example, asserted that if a firm's resources and capabilities are valuable, rare, inimitable, and non-substitutable, then they constitute a source of sustainable competitive advantage.
} 
Teece and Pisano (1994) and Teece, Pisano,and Shuen (1997) extended the RBV framework to dynamic markets, hence the origin of the popular term "dynamic capabilities." ${ }^{10}$ With reference to Augier and Teece (2007, p. 179):

Dynamic capabilities refer to the (inimitable) capacity firms have to shape, reshape, configure and reconfigure the firm's asset base so as to respond to changing technologies and markets. Dynamic capabilities relate to the firm's ability to proactively adapt in order to generate and exploit internal and external firm specific competencies, and to address the firm's changing environment.

Viewing innovation as a manifestation of the firm's dynamic capabilities, our heuristic conjecture is that such innovative behavior is influenced by the vocational background of the entrepreneur. It then becomes an empirical issue which dimensions of innovative behavior are so influenced. ${ }^{11}$

Our emphasis in this paper is limited to the firm's strategic choice to reveal its intellectual capital either as public knowledge (i.e., publications) or a private knowledge (i.e., patents). Quantitatively, we posit that:

$$
\text { innovative behavior }=\mathrm{f}(\text { entrepreneur's background, } \mathbf{X})
$$

where innovative behavior is characterized in two dimensions: if the firm's publishes its intellectual capital or alternatively if it patents it. The entrepreneur's background is also characterized in two dimensions: if the entrepreneur has a business background or if he has an academic background. The vector $\mathbf{X}$ controls for relevant research and firm characteristics.

\footnotetext{
${ }^{10}$ Teece, Pisano and Shuen (1997, p. 510) state: "Rudimentary efforts are made to identify the dimensions of firmspecific capabilities that can be sources of advantage, and to explain how combinations of competences and resources can be developed, deployed, and protected. We refer to this as the 'dynamic capabilities' approach in order to stress exploiting existing internal and external firm-specific competences to address changing environments."

${ }^{11}$ Dasgupta and David (1994) and Stern (2004) argue that personal preferences influence a researcher's choice between alternative property rights.
} 
We view our empirical analysis - that is our estimation of variations of equation (1) and discussion of the results_as a "quantitative case study" relying specifically on information about research projects conducted in small, entrepreneurial firms. Our analysis is based on firms that were awarded a SBIR Phase II award by the NIH, as discussed below.

This type of case study approach was first advocated by Cole (1946). ${ }^{12}$ Cole (1949, p. 88) defined entrepreneurship as:

... the purposeful activity (including an integrated sequence of decisions) of an individual or group of associated individuals, undertaken to initiate, maintain, or aggrandize a profit-oriented business unit for the production or distribution of economic goods and services with pecuniary or other advantage the goal or measure of success, in interaction with (or within the conditions established by) the internal situation of the unit itself or with the economic, political, and social circumstances (institutions and practices) of a period which allows an appreciable measure of freedom of decision.

This definition illustrates a major theme of the Harvard economic historians at that time, and a theme which motivates this paper, namely that entrepreneurship is associated with environmental characteristics (e.g., the firm's blueprint or its resources and dynamic capabilities) that influence the entrepreneur’s decision-making process (e.g., the distribution of intellectual capital).

Before describing our empirical model, which is motivated by our discussion in this section, we overview the dataset used in our analysis and we offer a descriptive interpretation of it in light of the hypotheses implicit in equation (1).

\footnotetext{
${ }^{12}$ In the wake of Schumpeter's treatment of economic development, a tradition of historical studies of entrepreneurship began at Harvard University's Research Center in Entrepreneurial History, established by Arthur H. Cole. Cole (1946) decried the neglect of the entrepreneur by economic historians and by economic theorists, advocating a case study approach that employed various methods, including cross-sectional investigations of specific individuals over time, longitudinal studies of particular entrepreneurial functions, and conceptual studies in historical entrepreneurship that might relate to contemporary issues. See Hébert and Link (forthcoming) for a more direct comparison between the views of Schumpeter and Cole.
} 


\section{Data and Descriptive Findings}

The Small Business Innovation Development Act of 1982 (P. L. 97-219) mandated that all government agencies with external research programs of greater than $\$ 100$ million establish their own SBIR program and set aside a percentage of their external research budget to support small firms' innovative activities. The 1982 Act stated the objectives of the SBIR program are to: (1) stimulate technological innovation, (2) use small business to meet Federal research and development needs, (3) foster and encourage participation by minority and disadvantaged persons in technological innovation, and (4) increase private sector commercialization of innovation derived from Federal research and development.

As part of the 1982 Act, SBIR program awards were structured as defined by three phases (National Research Council 2004; Wessner 2008). ${ }^{13}$ Phase I awards are small, generally less than $\$ 100,000$ for the six month award period. The purpose of Phase I awards is to assist businesses as they assess the feasibility of an idea's scientific and commercial potential in response to the funding agency’s objectives. Phase II awards typically range up to $\$ 750,000$ over two years. ${ }^{14}$ These awards are for the business to develop further its proposed research, ideally leading to a commercializable product, process, or service. ${ }^{15}$ The Phase II awards of public funds for development are sometimes augmented by outside private funding (Wessner 2000). Further work on the projects launched through the SBIR program occurs in what is called Phase III, which does not involve SBIR funds. At this stage businesses needing additional financing - to ensure that the product, process, or service can move into the marketplace-are expected to obtain it from sources other than the SBIR program.

Since 1982, the program has been authorized by Congress several times. In 1992, the program was reauthorized until 2000 through the Small Business Research and Development Enactment Act. Under the 1982 Act, the set aside had increased from 0.20 percent to 1.25 percent of the external research budget; the 1992 reauthorization raised that amount over time to the current set

\footnotetext{
${ }^{13}$ A small firm must be at least 51 percent owned by U.S. citizens or lawfully admitted permanent resident aliens, and it cannot employ more than 500 workers to apply for an SBIR award. The majority of firms that receive SBIR awards have less than 20 employees.

${ }^{14}$ It is not uncommon, however, for NIH Phase II awards to exceed the $\$ 750,000$ threshold.

${ }^{15}$ About one-third of Phase I awardees applying for Phase II awards are funded.
} 
aside of 2.50 percent. $^{16}$ In addition to re-emphasizing the commercialization intent of SBIRfunded technologies, the 1992 reauthorization broadened objective (3) above to focus also on women: "to provide for enhanced outreach efforts to increase the participation of ... small businesses that are 51 percent owned and controlled by women.” The Small Business Reauthorization Act of 2000 extended the SBIR program until 2008 and maintained the 2.50 percent set aside. ${ }^{17}$

The Act of 2000 also mandated that, among other things, the National Research Council (NRC) within the U.S. National Academies conduct "an evaluation of the economic benefits achieved by the SBIR program" and make recommendations for "improvements to the SBIR program.” In response, the NRC constructed a survey-based database on SBIR awarded projects for five agencies: Department of Defense (DoD), National Institutes of Health (NIH) within Health and Human Services, NASA, Department of Energy (DoE) and the National Science Foundation (NSF). These five agencies account for nearly 97 percent of the program's expenditures. ${ }^{18}$

Between 1992 and 2001, 2,497 Phase II SBIR project awards were made by NIH. ${ }^{19}$ Of these, 1,672 (67.0 percent of the total) were randomly selected by the NRC to receive an in-depth

\footnotetext{
${ }^{16}$ Current annual SBIR awards in the eleven participating agencies total over $\$ 2$ billion. These agencies are, in descending order of award funding: Department of Defense, Health and Human Services (primarily NIH), Department of Energy, NASA, National Science Foundation, Department of Agriculture, Department of Homeland Security, Department of Education, Department of Commerce, Environmental Protection Agency, and the Department of Transportation.

${ }^{17}$ A more detailed history of SBIR is in Link and Ruhm (forthcoming) and Wessner (2004, 2008). In April 2008, the U.S. House of Representatives passed H.R. 5819, the SBIR/STTR Reauthorization Act of 2008. However, the Senate Committee on Small Business and Entrepreneurship (SBE) passed their own version of the SBIR/STTR Reauthorization Act of 2008, S. 3362. Among other things, Phase I funding would increase to $\$ 150,000$ and Phase II funding would increase to $\$ 1$ million, with a provision for these guidelines to be exceeded by $50 \%$. Also, the current $2.5 \%$ set aside would increase to $3.5 \%$ at a rate of .1\% over 10 years, except for $\mathrm{NIH}$, which would stay at 2.5\%. S. 3362 would not have passed by the critical September 30, 2008 deadline; P.L. 110-235 temporarily extended the existing SBIR Act until 2009.

${ }^{18}$ In 2005, the most recent year of cross-agency comparable data, NIH granted 732 of the 4,031 Phase I awards and 369 of the 1,842 Phase II awards. NIH’s awards in that year totaled \$562.1 million, compared to a total of \$1,851.0 million by all eleven agencies.

${ }^{19}$ The NRC surveys were administered in mid-2005, thus building in a four-year lag for 2001 Phase II projects to be completed. The database does not cover projects funded under the related Small Business Technology Transfer (STTR) program, which has similar aims but different eligibility requirements.
} 
survey related to outputs associated with the funded project. The NRC's random sample was chosen to ensure balanced coverage by year and by number of Phase II awards received each year between 1992 and 2001. From the 1,672 random projects, 488 completed or partiallycompleted surveys were returned to the NRC. Phase II research was not yet finished in 34 projects with completed surveys, and another 58 projects did not provide all of the information needed for our analysis (discussed below). The final sample analysis sample consisted of 396 research projects conducted by 295 firms. See Table 1.

This is an appropriate database for our quantitative case study for at least three reasons. One, all of the firms in the database are entrepreneurial firms engaged in research (i.e., innovative activity); two, because the firm's are small (discussed below with reference to Table 2), it is more likely that the influence of the entrepreneur's background will be uniquely identifiable; and three, a research project is the unit of analysis, facilitating our ability to segment and observe a firm's strategic choice of revealing its intellectual capital solely in terms of publishing or solely in terms of patenting.

The dependent variable in equation (1), innovative behavior, is approximated in terms of publication activity and patenting activity. Publication activity is measured in three ways: pubonly $=1$ if the output from the completed Phase II project was publications and not patents, and 0 otherwise; publish $=1$ if the output from the completed Phase II project was publications whether or not patents were also an output, and 0 otherwise; and pubs = the number of scientific publications as of the survey date. Patenting activity is measured similarly: patonly $=1$ if the output from the completed Phase II project was patents and not publications, and 0 otherwise; patent $=1$ if an output from the completed Phase II project was patents whether or not publications were also an output, and 0 otherwise; and pats = number of patents by the time of the survey. ${ }^{20}$

\footnotetext{
${ }^{20}$ Papers submitted for publication but not yet published, and patents applied for but not yet granted, were not included in these measures.
} 
The variables pubonly and patonly follow broadly from Bush's (1945) dichotomy of basic research and applied research. ${ }^{21}$ Bush viewed these activities as substitutes at a point in time with applied research invariably driving out basic or pure research. ${ }^{22}$ Over time, however, there is suggestive evidence that these activities may be complements (Geuna and Nesta 2006, Azoulay et al. 2006). These variables could also be viewed to reflect what Stokes (1997) referred to as characterizing Pasteur's Quadrant or use-inspired research.

The focal independent variable in equation (1), entrepreneur's background, is also measured in three ways: busonly $=1$ if at least one founder of the firm had a business background and other founders (if any) did not have an academic background, and 0 otherwise; aconly = 1 if at least one founder had an academic background and the other founders (if any) did not have a business background, and 0 otherwise; and other $=1$ for all other founder combinations including if the firm had one founder with neither a business nor an academic background. ${ }^{23}$

The controls in vector $\mathbf{X}$ include in our parsimonious specifications if a university was involved with the SBIR Phase II research project (univ = 1), or not (univ = 0); and the total number of firm founders, numfound.

Descriptive statistics on all variables, including those used in subsequent regressions discussed below, are in Table 2. Based on the descriptive statistics, more Phase II projects resulted in publications than patents regardless of how those activities are measured. For instance,

\footnotetext{
${ }^{21}$ According to Bush (1945, p. 13): "Basic research is performed without thought of practical ends. It results in general knowledge and an understanding of nature and its laws. This general knowledge provides the means of answering a large number of important practical problems, though it may not give a complete specific answer to any one of them. The function of applied research is to provide such complete answers."

${ }^{22}$ Stokes $(1997$, p. 8) took issue with this view. He described the goal of basic research as "understanding," and the goal of applied research as "use." At a point in time (p. 12): "The belief that the goals of understanding and use are inherently in conflict, and that the categories of basic and applied research are necessarily separate is itself in tension with the actual experience of science." Kane (2006, p. 545) argued that the "basic tools of scientific and technological work" — which are a foundation for much published research—are not patentable. See also, Mohammed (2008).

${ }^{23}$ Our measure of the entrepreneur's vocational background is limited by data availability. Ideally, we would have like to control for such characteristics as number of years within a university and responsibilities therein, as well as number of years within a business and responsibilities therein.
} 
publications resulted from over one-half of the Phase II projects and patents from about onethird. Also, 47 percent of the firms in the sample were exclusively founded by academics, and 45 percent had multiple founders from various backgrounds (but still the overall mean was only 2 founders). Only 8 percent of firms were founded exclusively by persons with business backgrounds. Over one-half of the Phase II projects involved a university as a research partner and average firm size, at the start of the Phase II project, was 19 employees.

Tables 3 and 4 anticipate the regression results that follow. Table 3 divides the sample into three groups: the 186 projects undertaken by firms with only academic entrepreneurs ( $a$ conly $=1$ ); the 32 projects by firms with only business founders (busonly $=1$ ), and the 178 projects occurring in firms with other founder combinations (other $=1$ ). ${ }^{24}$ Nearly 35 percent of the projects within firms with only academic entrepreneurs resulted in publications but not patents (pubonly $=1$ ), compared to 25 percent of those within firms with only business founders. Similarly, just over 9 percent of the project within firms with only academic entrepreneurs resulted in patents, compared to just over 28 percent of the projects within firms with only business founders. Firms with only business founders are somewhat more likely to both publish and patent than those with only academic founders (25 percent versus 18 percent) and they are less likely to engage in neither activity (22 percent versus 38 percent). Firms with other combinations of founders fall between the academic only and business only firms.

Table 4 divides the sample of projects into two different groups, the 130 projects resulting in publications but not patents (pubonly $=1$ ) and the 56 projects leading to patents but not publications (patonly $=1$ ). Fifty percent of publish-only projects compared to 30.4 percent of patent-only projects, were within academic entrepreneurial firms. Similarly, just over 6 percent of publish-only projects were within business entrepreneurial firms compared to just over 16 percent of patent-only projects.

\section{Econometric Estimates}

\footnotetext{
${ }^{24}$ This group includes firms with both academic and business founders as well as all firm that have at least one founder without either an academic or business background.
} 
Based on the descriptive information in Tables 3 and 4, and on the premise that academic entrepreneurs are from a culture or environment guided by the creation and distribution of knowledge as a public good, while business entrepreneurs are from a culture or environment guided by the appropriation of knowledge for competitive gain, we hypothesize a positive relationship between business entrepreneurial firms and patenting activity from its research projects, ceteris paribus (relative to academic entrepreneurial firms) and a corresponding negative relationship with publication activity.

In our initial estimatable versions of equation (1) we control for the presence of a university, univ, as a research partner. We posit a positive relationship between the presence of a university and the publication output from the research project, holding constant the background of the entrepreneur, and a negative relationship with patenting activity.

We also control for the number of firm founders (numfound), a measure of the scope of its capable activities. We do not posit a relationship between the scope or size of a firm and how it reveals its intellectual capital. On the one hand, larger firms may have the internal resources to pursue both a publication and patenting strategy for a given project, holding constant the background of the entrepreneur. In this case, size should not have a statistical impact when publications only or patents only are the dependent variable. On the other hand, a minimum size may be needed before a firm can devote resources to either publishing or patenting. If so, it should have a positive statistical impact when the number of publications or patents is the dependent variable. ${ }^{25}$

Potential concerns about selection bias that exist with any empirical analysis of survey data, are especially applicable in this study, since only 23.7 percent of the survey sample is being analyzed. $^{26}$ We partially addressed this issue by estimating variations of equation (1) simultaneously with a model of the probability of response to the project survey. The response model was structured as a function of the number of years since the Phase II award was received,

\footnotetext{
${ }^{25}$ The results in Tables 5 and 6 below are not materially changed by controlling for a quadratic in size, to allow for non-linear effects.

${ }^{26}$ This percentage reflects 396 project responses from a random survey population of 1,672 projects; see Table 1.
} 
years. Absent a theoretical foundation for why some firms would respond to the survey for a particular project, we posit that the older the Phase II award the less institutional knowledge that still exists within the firm for that project and the less able and likely the firm would be to respond to the survey. A negative correlation between years and the probability of response was confirmed by our econometric estimates $(n=1,672)$, but when variations of equation (1) were estimated simultaneously there was no indication of selection bias. Specifically the estimates always failed to reject the null hypothesis that the models of response and intellectual capital outputs are independent of one another. ${ }^{27}$ Thus, the econometric results that follow are for single-equation models that do not account for selection.

The econometric findings in Table 5 use various types of publications as the dependent variables. Specifically, we estimate probit models in the case of the two dichotomous outcomes (pubonly and pubs) and a negative binominal model for the number of publications (pubs). The table shows the predicted effect of a one unit change in the explanatory variable on the outcome. These marginal effects are calculated with all other covariates evaluated at the sample means. The reference group consists of projects in firms with academic founders only. Models (a) and (b) differ in that the latter adds controls for the supplementary explanatory variables detailed in Table 2.

The estimated marginal effect from busonly is negative for all three dependent variables. Although the estimates are usually not precise enough to rule out the null hypothesis of no effect (i.e., statistical significance), the magnitudes of point estimates are substantial (i.e., economic significance): in the parsimonious specification (model (a)) a business entrepreneurial firm correlates with a 9.5 percentage point decrease in the probability that a Phase II project's will only intellectual capital will be publications (1a), a 2.7 point decrease in the probability that they publish at all (2a), and a .856 article decrease in the number of scientific publications (3a). Because the sample means for these dependent variables are 32.8 percent, 52.5 percent and 2.6 publications, the first and last of these predicted effects are economically significant. These estimates increase in magnitude when including the full set of controls and the predicted impact on the number of publications becomes statistically significant.

\footnotetext{
${ }^{27}$ These results are available from the authors upon request.
} 
Compared to firms with academic entrepreneurs only, the residual "other” category of founders is predicted to reduce the probability that the firm publishes but does not patent and to significantly increase the number of publications.

The presence of a university as a research partner does have a positive and significant effect on publications. In fact, the positive university effect outweighs the negative predicted business entrepreneur effect in all three models. ${ }^{28}$

Our control, numfound, is not significantly related to the probability of publishing, but it is positively related to the number of publications. $^{29}$

As reported in Table 6, business entrepreneurs have a positive, significant, and large impact on patenting activity. For example, firms with business entrepreneurs only are predicted to be 20.5 percentage points more likely than their counterpart firms made up exclusively of academic founders, to have patents as their only research output (1a), 26.2 points more likely to patent at all (2a), and they produce .326 additional patents (3a). The first two of these effects are statistically significant (at the .01 level or better) and all are of substantial magnitude.

Other founder types are more likely to engage in all of the types of the patenting behaviors examined than the reference group (academic founders only) but less likely to do so than firms with business entrepreneurs only. Conversely, the presence of a university research partner reduces all types of patenting behavior, although the predicted negative effect is only significant in columns (1a and 1b). As in Table 5, scale is generally not economically important, although

\footnotetext{
${ }^{28}$ This last result may be slightly misleading if firms with business entrepreneurs are less likely to have university involvement than those with academic entrepreneurs. The actual difference is quite small ( $53.1 \%$ of the former versus $54.3 \%$ of the latter). Specifications corresponding to those in model (a), except without controlling for university involvement, yield marginal larger negative predicted effects of firms led by business-only entrepreneurs on patenting (and slightly stronger positive results for patenting below). Relatedly, Stuart et al. (2007) found that biotechnology firm founders with academic ties are more likely to enter into formal technology agreements with universities.

${ }^{29}$ Alternatively, we measured firm size as the number of employees in the firm at the time of the Phase II award (empstart). See Table 1. The same results hold. These results are available from the authors upon request.
} 
there is a statistically significant positive relationship between the number of founders and the probability of patenting.

Finally, Table 7 reports the marginal effects from multinominal logit models where the outcomes are patenting only, publishing only, doing both, or doing neither. In general, the results are consistent with those in Tables 5 and 6. For example, in the model without supplementary covariates, having a business founder increases the predicted probability that a firm only patents by a statistically significant 21.4 percentage points; the corresponding marginal effect was 20.5 percentage points in Table 6. As in the previous models, firms with business founders are statistically insignificantly less likely to publish university involvement increases publication activity but decreases patenting.

\section{Discussion}

[If] the United States wishes to continue enjoying rapid growth, it must find a way both to launch and promote the growth of innovation entrepreneurial enterprises and to ensure that the successful entrepreneurs who grow their businesses into large firms continue to innovate. We believe that this requires policies that encourage what we call "productive entrepreneurship.”

This view, advocated by Baumol, Litan, and Schramm (2007, p. 2), raises that at least two important issues. ${ }^{30}$ One issue is that it is imperative to understand the breadth of activities associated with innovative entrepreneurs, especially entrepreneurs who are affected by whatever policies or "rules of the game" that might be in place; and two, how those activities might impact society. $^{31}$

Baumol (1990, p. 3) has argued:

\footnotetext{
${ }^{30}$ Baumol, Litan, and Schramm (2007) complete their charge by suggesting a number of policy initiatives that should be considered, ranging from tax policies to encourage risk taking, to reforming bankruptcy laws to promote the formation of new businesses, to revising the patent system. Such actions will "adjust the rules of the game to induce a more felicitous allocation of entrepreneurial resources” (Baumol 1990, p. 4).

${ }^{31}$ Link and Link (forthcoming) make the case that government can similarly act as entrepreneur.
} 
[Entrepreneurs] are always with us and always play some substantial role. But there are a variety of roles among which the entrepreneur's efforts can be reallocated, and some of those roles do not follow the constructive and innovative script that in conventionally attributed to that person. Indeed, at times the entrepreneur may even lead a parasitical existence that is actually damaging to the economy. How the entrepreneur acts at a given time and place depend heavily on the rules of the game - the reward structure in the economy - that happens to prevail. Thus ... it is the set of rules and not the supply of entrepreneurs or the nature of their objectives that undergoes significant changes form one period to another and helps to dictate the ultimate effect on the economy via the allocation of entrepreneurial resources.

Thus, within the current rules of the game, the findings from our quantitative case study show that publicly-financed research through the SBIR program has generated intellectual capital and that capital takes the form of public knowledge as well as private knowledge. Certainly, our analysis is insufficient to offer any judgment with regard to whether SBIR-induced public versus private knowledge has the greater impact on society, but our analysis is sufficient to represent a first step toward understanding that both forms of knowledge do result from publicly-financed research and that the extent to which such knowledge enters society is not random but rather directly related with the culture and environment from which the entrepreneur came.

Our analysis does suggest, however, to the extent that the behavior of small firms that spinout from a university is similar to the behavior of small SBIR-recipient firms founded by academics, that one social benefit associated with spinouts will be intellectual capital that takes on the form of a public good through the publication process. The creation and distribution of public knowledge, which is an implicit objective of a university (and likely an explicit objective of many), from spinouts may comfort many university administrators and faculty that there are indeed positive externalities associated with internal entrepreneurial efforts that do in fact complement the basic educational mission of the university. University involvement may also increase the public knowledge generation of small firms that do not spinout directly from them, possibly by reorienting or reinforcing the entrepreneurial culture of the firm. 
Our analysis also shows that entrepreneurial firms tradeoff publications and patents. This tradeoff may reflect the heterogeneous nature of the research conducted during the Phase II award (for which we do not have good controls). But is may also reflect a purposeful strategic decision by firms. If policy makers view, at the margin, the social benefits of public knowledge to be greater than the social benefits of private knowledge, ceteris paribus, then they may consider incentives for SBIR applicants to publish rather than to patent. Based on our results we suggest, cautiously, that one way to do this might be to give funding priority to those Phase II applicants that will include an academic founder or a university as a research partner. ${ }^{32}$

${ }^{32}$ Link and Ruhm (forthcoming) have shown that including universities as a research partner also increases the probability of commercialization from NIH-funded Phase II research. 


\section{Table 1}

Sample of NIH Phase II Projects Awarded between 1992 and 2001

Data Reduction

Number of Projects

Population of NIH Projects from the NRC Database

2,497

Random Survey Population

1,672

Survey Respondents

488

Respondents with Completed Phase II Projects

454

Survey Respondents Reporting All Relevant Information 
Table 2

Descriptive Statistics for the Analysis Sample $(n=396)$

\begin{tabular}{|c|c|c|c|c|c|}
\hline Variable Description & Variable & Mean & $\begin{array}{l}\text { Standard } \\
\text { Deviation }\end{array}$ & Minimum & Maximum \\
\hline \multicolumn{6}{|l|}{ Dependent Variables } \\
\hline Publications Only & pubonly & .328 & .47 & 0 & 1 \\
\hline Some Publications & publish & .525 & .50 & 0 & 1 \\
\hline \# of Publications & pubs & 2.60 & 9.83 & 0 & 165 \\
\hline Patents Only & patonly & .141 & .349 & 0 & 1 \\
\hline Some Patents & patent & .338 & .474 & 0 & 1 \\
\hline \# of Patents & pats & .689 & 1.62 & 0 & 20 \\
\hline \multicolumn{6}{|l|}{ Main Explanatory Variables } \\
\hline Business Founders Only & busonly & .081 & .273 & 0 & 1 \\
\hline Academic Founders Only & aconly & .470 & .500 & 0 & 1 \\
\hline Other Founder Combinations & other & .449 & .498 & 0 & 1 \\
\hline University Involvement & univ & .515 & .50 & 0 & 1 \\
\hline Firm's \# of Founders & numfound & 2.06 & 1.81 & 0 & 20 \\
\hline \multicolumn{6}{|l|}{ Supplementary Explanatory Variables } \\
\hline Years Since SBIR Award Received & years & 7.24 & 2.57 & 4 & 13 \\
\hline \# of Employees at Project Start & empstart & 19.37 & 38.81 & 0 & 300 \\
\hline SBIR Project Amount (\$) & amount & 653,894 & 210,729 & 14,834 & $1,644,022$ \\
\hline Female Firm Owner & female & .179 & .384 & 0 & 1 \\
\hline Nonwhite Firm Owner & nonwhite & .061 & .239 & 0 & 1 \\
\hline \# Previous SBIR Phase I Awards & preph1 & 4.63 & 16.44 & 0 & 172 \\
\hline \# Previous SBIR Phase II Awards & preph2 & 2.10 & 7.20 & 0 & 79 \\
\hline Firm Started Due to SBIR Program & sbirstart & .116 & .321 & 0 & 1 \\
\hline
\end{tabular}


Table 3

Form of Intellectual Capital by Entrepreneur's Background

\begin{tabular}{lcccc}
\hline \multirow{2}{*}{ Type of Founder } & \multicolumn{3}{c}{ Form of Intellectual Capital } \\
\cline { 2 - 4 } & Publish Only & Patent Only & $\begin{array}{c}\text { Publish and } \\
\text { Patent }\end{array}$ & Neither \\
\hline All Projects (n=396) & $32.8 \%$ & $14.1 \%$ & $19.7 \%$ & $33.3 \%$ \\
Academic Only (n=186) & $34.9 \%$ & $9.1 \%$ & $17.7 \%$ & $38.2 \%$ \\
Business Only (n=32) & $25.0 \%$ & $28.1 \%$ & $25.0 \%$ & $21.9 \%$ \\
Other (n=178) & $32.0 \%$ & $16.9 \%$ & $20.8 \%$ & $30.3 \%$ \\
\hline
\end{tabular}

Note: The table rows show the percentages of projects with the specified type of firm founder producing the forms of intellectual capital listed in the column headings. 
Table 4

Entrepreneur's Background by Form of Intellectual Capital

\begin{tabular}{lccc}
\hline \multirow{2}{*}{ Intellectual Capital } & \multicolumn{3}{c}{ Type of Founder } \\
\cline { 2 - 4 } & Academic Only & Business Only & Other \\
\hline All Projects $(\mathrm{n}=396)$ & $47.0 \%$ & $8.1 \%$ & $44.9 \%$ \\
Publish Only (n=130) & $50.0 \%$ & $6.2 \%$ & $43.8 \%$ \\
Patent Only ( $\mathrm{n}=56)$ & $30.4 \%$ & $16.1 \%$ & $53.6 \%$ \\
Patent and Publish (n=78) & $42.3 \%$ & $10.3 \%$ & $47.4 \%$ \\
Neither (n=132) & $53.8 \%$ & $5.3 \%$ & $40.9 \%$ \\
\hline
\end{tabular}

Note: The table rows show the percentages of projects producing the specified form of intellectual capital that have the type of firm founder listed in the column headings. 


\section{Table 5}

Econometric Estimates of the Marginal Effects on Publishing Behavior

(standard errors are in parentheses; $\mathrm{n}=396$ )

\begin{tabular}{lcccccc}
\hline \multirow{2}{*}{ Independent Variable } & \multicolumn{7}{c}{ Dependent Variable } \\
\cline { 2 - 7 } & \multicolumn{3}{c}{ Publish Only } & \multicolumn{2}{c}{ Publish } & \multicolumn{2}{c}{ \# Publications } \\
& $\mathbf{( 1 a )}$ & $\mathbf{( 1 b )}$ & $\mathbf{( 2 a )}$ & $\mathbf{( 2 b )}$ & $\mathbf{( 3 a )}$ & $\mathbf{( 3 b )}$ \\
\hline Business Founder Only & -.095 & -.106 & -.027 & -.059 & -.856 & $-.960^{* *}$ \\
(busonly) & $(.082)$ & $(.082)$ & $(.097)$ & $(.100)$ & $(.526)$ & $(.449)$ \\
Other Founder Type & -.017 & -.010 & .008 & -.006 & $.927^{* *}$ & $.710^{* * *}$ \\
(other) & $(.051)$ & $(.052)$ & $(.055)$ & $(.057)$ & $(.448)$ & $(.398)$ \\
Number of Founders & -.007 & -.010 & .005 & .003 & $.436^{* *}$ & $.257^{* * *}$ \\
(numfound) & $(.014)$ & $(.014)$ & $(.015)$ & $(.015)$ & $(.173)$ & $(.150)$ \\
University Involvement & $.113^{* *}$ & $.109 * *$ & $.180^{*}$ & $.179 *$ & $1.87 *$ & $1.56^{*}$ \\
(univ) & $(.047)$ & $(.049)$ & $(.050)$ & $(.052)$ & $(.435)$ & $(.390)$ \\
\hline $\begin{array}{l}\text { Supplementary } \\
\text { Covariates }\end{array}$ & No & Yes & No & Yes & No & Yes \\
Pseudo R-squared & .0143 & .0299 & .0242 & .0670 & .0320 & .0485 \\
Log Pseudo-Likelihood & -247.07 & -242.77 & -267.34 & -254.92 & -733.56 & -720.33 \\
\hline
\end{tabular}

Note: $*=$ significant at the .01 level, $* *=$ significant at the .05 level, $* * *=$ significant at the .10 level.

Columns (1a) through (2b) are estimated as probit models, and columns (3a) and (3b) as negative binomial models. The table displays marginal effects with other covariates evaluated at the sample means. The reference group includes firms with academic founders only. Supplementary covariates include dummy variables for female (female) and nonwhite (nonwhite) owners and whether the firm was started as the result of an SBIR award (sbirstart); also included are continuous variables for the amount of the SBIR award (amount), the number of firm employees at the time of the SBIR award (empstart), years since the SBIR was awarded (years), and the firms number of previous Phase I and Phase II SBIR awards (preph1, preph2). These results are in Appendix Table A.1. 


\section{Table 6}

Econometric Estimates of the Marginal Effects on Patenting Behavior

(standard errors are in parentheses; $\mathrm{n}=396$ )

\begin{tabular}{|c|c|c|c|c|c|c|}
\hline \multirow{3}{*}{ Independent Variable } & \multicolumn{6}{|c|}{ Dependent Variable } \\
\hline & \multicolumn{2}{|c|}{ Patent Only } & \multicolumn{2}{|c|}{ Patent } & \multicolumn{2}{|c|}{ \# Patents } \\
\hline & (1a) & (1b) & (2a) & (2b) & (3a) & (3b) \\
\hline $\begin{array}{l}\text { Business Founder Only } \\
\text { (busonly) }\end{array}$ & $\begin{array}{l}.205^{*} \\
(.093)\end{array}$ & $\begin{array}{l}.185^{* *} \\
(.092)\end{array}$ & $\begin{array}{l}.262 * \\
(.094)\end{array}$ & $\begin{array}{l}.238^{* *} \\
(.099)\end{array}$ & $\begin{array}{l}.326 \\
(.353)\end{array}$ & $\begin{array}{l}.196 \\
(.276)\end{array}$ \\
\hline $\begin{array}{l}\text { Other Founder Type } \\
\text { (other) }\end{array}$ & $\begin{array}{l}.058 \\
(.038)\end{array}$ & $\begin{array}{l}.043 \\
(.037)\end{array}$ & $\begin{array}{l}.084 \\
(.052)\end{array}$ & $\begin{array}{l}.053 \\
(.053)\end{array}$ & $\begin{array}{l}.373^{* *} \\
(.156)\end{array}$ & $\begin{array}{l}.281^{* *} \\
(.133)\end{array}$ \\
\hline $\begin{array}{l}\text { Number of Founders } \\
\text { (numfound) }\end{array}$ & $\begin{array}{l}.012 \\
(.008)\end{array}$ & $\begin{array}{l}.012 \\
(.008)\end{array}$ & $\begin{array}{c}.026 * * * \\
(.014)\end{array}$ & $\begin{array}{c}.026 * * * \\
(.014)\end{array}$ & $\begin{array}{l}.018 \\
(.041)\end{array}$ & $\begin{array}{l}.010 \\
(.035)\end{array}$ \\
\hline $\begin{array}{l}\text { University Involvement } \\
\text { (univ) }\end{array}$ & $\begin{array}{l}-.108^{*} \\
(.035)\end{array}$ & $\begin{array}{l}-.120^{*} \\
(.035)\end{array}$ & $\begin{array}{l}-.043 \\
(.048)\end{array}$ & $\begin{array}{l}-.070 \\
(.050)\end{array}$ & $\begin{array}{l}-.028 \\
(.132)\end{array}$ & $\begin{array}{l}-.067 \\
(.119)\end{array}$ \\
\hline $\begin{array}{l}\text { Supplementary } \\
\text { Covariates }\end{array}$ & No & Yes & No & Yes & No & Yes \\
\hline Pseudo R-squared & .0636 & .1125 & .0287 & .0991 & .0085 & .0371 \\
\hline Log Pseudo-Likelihood & -151.11 & -143.09 & -246.16 & -227.93 & -433.91 & -421.03 \\
\hline
\end{tabular}

Note: $*=$ significant at the .01 level, $* *=$ significant at the .05 level, $* * *=$ significant at the .10 level.

Columns (1a) through (2b) are estimated as probit models, and columns (3a) and (3b) as negative binomial models. The table displays marginal effects with other covariates evaluated at the sample means. The reference group includes firms with academic founders only. Supplementary covariates include dummy variables for female (female) and nonwhite (nonwhite) owners and whether the firm was started as the result of an SBIR award (sbirstart); also included are continuous variables for the amount of the SBIR award (amount), the number of firm employees at the time of the SBIR award (empstart), years since the SBIR was awarded (years), and the firms number of previous Phase I and Phase II SBIR awards (preph1, preph2). These results are in Appendix Table A.1. 


\section{Table 7}

Multinomial Logit Estimates of the Marginal Effects on the Form of Intellectual Capital (standard errors are in parentheses; $\mathrm{n}=396$ )

\begin{tabular}{|c|c|c|c|c|c|c|c|c|}
\hline \multirow{3}{*}{$\begin{array}{l}\text { Independent } \\
\text { Variable }\end{array}$} & \multicolumn{8}{|c|}{ Form of Intellectual Capital } \\
\hline & \multicolumn{2}{|c|}{ Patent Only } & \multicolumn{2}{|c|}{ Publish Only } & \multicolumn{2}{|c|}{$\begin{array}{l}\text { Patent and } \\
\text { Publish }\end{array}$} & \multicolumn{2}{|c|}{ Neither } \\
\hline & (1a) & (1b) & (2a) & (2) & (3a) & (3b) & (4a) & $(4 b)$ \\
\hline $\begin{array}{l}\text { Business Founder } \\
\text { Only (busonly) }\end{array}$ & $\begin{array}{l}.214^{* *} \\
(.098)\end{array}$ & $\begin{array}{l}.202 * * \\
(.098)\end{array}$ & $\begin{array}{l}-.114 \\
(.080)\end{array}$ & $\begin{array}{l}-.119 \\
(.086)\end{array}$ & $\begin{array}{c}.056 \\
(.084)\end{array}$ & $\begin{array}{c}.047 \\
(.082)\end{array}$ & $\begin{array}{c}-.157 * * \\
(.074)\end{array}$ & $\begin{array}{l}-.130 \\
(.085)\end{array}$ \\
\hline $\begin{array}{l}\text { Other Founder } \\
\text { Type (other) }\end{array}$ & $\begin{array}{l}.061 \\
(.038)\end{array}$ & $\begin{array}{l}.047 \\
(.038)\end{array}$ & $\begin{array}{l}-.022 \\
(.051)\end{array}$ & $\begin{array}{l}-.016 \\
(.055)\end{array}$ & $\begin{array}{l}.022 \\
(.045)\end{array}$ & $\begin{array}{c}.003 \\
(.044)\end{array}$ & $\begin{array}{l}-.061 \\
(.051)\end{array}$ & $\begin{array}{l}-.034 \\
(.054)\end{array}$ \\
\hline $\begin{array}{l}\text { Number of } \\
\text { Founders } \\
\text { (numfound) }\end{array}$ & $\begin{array}{c}.014 * * * \\
(.008)\end{array}$ & $\begin{array}{c}.015^{* * *} \\
(.008)\end{array}$ & $\begin{array}{l}-4.5 \mathrm{E}-6 \\
(.016)\end{array}$ & $\begin{array}{c}-.001 \\
(.017)\end{array}$ & $\begin{array}{l}.014 \\
(.011)\end{array}$ & $\begin{array}{c}.015 \\
(.011)\end{array}$ & $\begin{array}{l}-.028 \\
(.019)\end{array}$ & $\begin{array}{l}-.028 \\
(.021)\end{array}$ \\
\hline $\begin{array}{l}\text { University } \\
\text { Involvement } \\
\text { (univ) }\end{array}$ & $\begin{array}{l}-.109 * \\
(.034)\end{array}$ & $\begin{array}{l}-.117 * \\
(.035)\end{array}$ & $\begin{array}{l}.113^{* *} \\
(.048)\end{array}$ & $\begin{array}{l}.125^{* *} \\
(.050)\end{array}$ & $\begin{array}{l}.066 \\
(.040)\end{array}$ & $\begin{array}{c}.058 \\
(.040)\end{array}$ & $\begin{array}{l}-.070 \\
(.048)\end{array}$ & $\begin{array}{l}-.065 \\
(.051)\end{array}$ \\
\hline $\begin{array}{l}\text { Supplementary } \\
\text { Covariates }\end{array}$ & No & Yes & No & Yes & No & Yes & No & Yes \\
\hline
\end{tabular}

Note: * = significant at the .01 level, $* *=$ significant at the .05 level, $* * *=$ significant at the .10 level.

The table displays marginal effects of the independent variable on the probability of producing the specified form of intellectual capital. The estimates are obtained from multinomial logit models, with other covariates evaluated at the sample means. The reference group includes firms with academic founders only. Supplementary covariates include dummy variables for female (female) and nonwhite (nonwhite) owners and whether the firm was started as the result of an SBIR award (sbirstart); also included are continuous variables for the amount of the SBIR award (amount), the number of firm employees at the time of the SBIR award (empstart), years since the SBIR was awarded (years), and the firms number of previous Phase I and Phase II SBIR awards (preph1, preph2). 


\section{Appendix Table A.1 \\ Econometric Estimates for Supplementary Covariates}

(standard errors are in parentheses; $\mathrm{n}=396$ )

\begin{tabular}{|c|c|c|c|c|c|c|}
\hline \multirow[b]{2}{*}{$\begin{array}{l}\text { Independent } \\
\text { Variable }\end{array}$} & \multicolumn{6}{|c|}{ Dependent Variable } \\
\hline & $\begin{array}{c}\text { Publish } \\
\text { Only }\end{array}$ & Publish & $\begin{array}{c}\# \\
\text { Publications }\end{array}$ & $\begin{array}{c}\text { Patent } \\
\text { Only }\end{array}$ & Patent & \# Patents \\
\hline $\begin{array}{l}\text { \# of Employees at } \\
\text { Project Start (empstart) }\end{array}$ & $\begin{array}{l}-8.9 \mathrm{E}-4 \\
(7.3 \mathrm{E}-4)\end{array}$ & $\begin{array}{c}-1.2 \mathrm{E}-3 * * * \\
(7.2 \mathrm{E}-4)\end{array}$ & $\begin{array}{c}.003 \\
(.005)\end{array}$ & $\begin{array}{l}-4.6 \mathrm{E}-4 \\
(4.5 \mathrm{E}-4)\end{array}$ & $\begin{array}{l}-1.0 \mathrm{E}-3 \\
(6.8 \mathrm{E}-4)\end{array}$ & $\begin{array}{l}-1.7 \mathrm{E}-3 \\
(1.8 \mathrm{E}-3)\end{array}$ \\
\hline $\begin{array}{l}\text { Female Company Owner } \\
\text { (female) }\end{array}$ & $\begin{array}{l}.003 \\
(.067)\end{array}$ & $\begin{array}{l}-.172 * * \\
(.071)\end{array}$ & $\begin{array}{l}-.642 \\
(.400)\end{array}$ & $\begin{array}{c}-.098^{* *} \\
(.033)\end{array}$ & $\begin{array}{l}-.286^{*} \\
(.049)\end{array}$ & $\begin{array}{l}-.577 * \\
(.102)\end{array}$ \\
\hline $\begin{array}{l}\text { Nonwhite Company } \\
\text { Owner (nonwhite) }\end{array}$ & $\begin{array}{l}-.094 \\
(.094)\end{array}$ & $\begin{array}{l}.141 \\
(.108)\end{array}$ & $\begin{array}{l}.309 \\
(.888)\end{array}$ & $\begin{array}{l}.073 \\
(.098)\end{array}$ & $\begin{array}{l}.331^{*} \\
(.123)\end{array}$ & $\begin{array}{l}.508 \\
(.471)\end{array}$ \\
\hline $\begin{array}{l}\text { SBIR Project Amount } \\
\text { (amount) }\end{array}$ & $\begin{array}{c}1.3 \mathrm{E}-7 \\
(1.2 \mathrm{E}-7)\end{array}$ & $\begin{array}{c}1.8 \mathrm{E}-7 \\
(1.3 \mathrm{E}-7)\end{array}$ & $\begin{array}{c}1.0 \mathrm{E}-6 \\
(8.1 \mathrm{E}-7)\end{array}$ & $\begin{array}{l}-3.2 \mathrm{E}-8 \\
(8.1 \mathrm{E}-8)\end{array}$ & $\begin{array}{c}2.1 \mathrm{E}-8 \\
(1.2 \mathrm{E}-7)\end{array}$ & $\begin{array}{c}4.1 \mathrm{E}-11 \\
(3.0 \mathrm{E}-11)\end{array}$ \\
\hline $\begin{array}{l}\text { Years Since SBIR } \\
\text { Award Received (years) }\end{array}$ & $\begin{array}{l}.005 \\
(.009)\end{array}$ & $\begin{array}{c}.019 * * * \\
(.010)\end{array}$ & $\begin{array}{l}.306^{*} \\
(.071)\end{array}$ & $\begin{array}{l}-.003 \\
(.006)\end{array}$ & $\begin{array}{l}.011 \\
(.009)\end{array}$ & $\begin{array}{l}.043^{* *} \\
(.022)\end{array}$ \\
\hline $\begin{array}{l}\text { \# Previous SBIR Phase I } \\
\text { Awards (preph1) }\end{array}$ & $\begin{array}{l}-.006 \\
(.008)\end{array}$ & $\begin{array}{l}.001 \\
(.008)\end{array}$ & $\begin{array}{l}-.015 \\
(.057)\end{array}$ & $\begin{array}{l}.007 \\
(.005)\end{array}$ & $\begin{array}{l}.020^{* *} \\
(.008)\end{array}$ & $\begin{array}{l}.011 \\
(.019)\end{array}$ \\
\hline $\begin{array}{l}\text { \# Previous SBIR Phase } \\
\text { II Awards (preph2) }\end{array}$ & $\begin{array}{l}.012 \\
(.017)\end{array}$ & $\begin{array}{l}-.001 \\
(.018)\end{array}$ & $\begin{array}{l}.040 \\
(.125)\end{array}$ & $\begin{array}{l}-.015 \\
(.011)\end{array}$ & $\begin{array}{l}-.040 \\
(.019)\end{array}$ & $\begin{array}{l}-.025 \\
(.045)\end{array}$ \\
\hline $\begin{array}{l}\text { Firm Started Due to } \\
\text { SBIR Program } \\
\text { (sbirstart) }\end{array}$ & $\begin{array}{c}-.126 * * * \\
(.067)\end{array}$ & $\begin{array}{l}-.237 * \\
(.077)\end{array}$ & $\begin{array}{c}-.828 * * \\
(.387)\end{array}$ & $\begin{array}{c}.111^{* * *} \\
(.069)\end{array}$ & $\begin{array}{c}.009 \\
(.079)\end{array}$ & $\begin{array}{c}-.186 \\
(.151)\end{array}$ \\
\hline
\end{tabular}

Note: $*=$ significant at the .01 level, $* *=$ significant at the .05 level, $* * *=$ significant at the .10 level.

See notes on Tables 5 and 6 . Estimates are from columns (1b), (2b) and (3b) of those tables. Table displays marginal effects from probit or negative binomial models. All models also include controls for the type of founder, university involvement and the firm's number of founders. 


\section{References}

Audretsch, David B. (2009). “The Entrepreneurial Society,” Journal of Technology Transfer, 34: $245-254$.

Augier, Mie and David J. Teece (2007). “Dynamic Capabilities and Multinational Enterprise: Penrosean Insights and Omissions,” Management International Review, 47: 175-192.

Azoulay, Pierre, Waverly Ding, and Toby Stuart (2006). “The Impact of Academic Patenting on the Rate, Quality, and Direction of (Public) Research Output,” NBER Working Paper No. W11917.

Barney, Jay. (1991). “Firm Resources and Sustained Competitive Advantage,” Journal of Management, 17: 99-120.

Baron, James N., Michael T. Hannan, and M. Diane Burton (1999). "Building the Iron Cage: Determinants of Managerial Intensity in the Early Years of Organizations,” American Sociological Review, 64: 527-547.

Baton, Robert A. and Michael D. Ensley (2006). “Opportunity Recognition as the Detection of Meaningful Patterns: Evidence from Comparisons of Novice and Experienced Entrepreneurs,” Management Science, 52: 1331-1344.

Baudeau, Nicholas (1910). Premiere Introduction a la Philosophie Economique (edited by A. Dubois), Paris: P. Geuthner (originally 1767).

Baumol, William F. (1990). “Entrepreneurship: Productive, Unproductive, and Destructive,” Journal of Business Venturing, 11: 3-22.

Baumol, William F., Robert E. Litan, and Carl J. Schramm (2007). "Sustaining Entrepreneurial Capitalism,” Capitalism and Society, 2: 1-36.

Bush, Vannevar (1945). Science-the Endless Frontier: A Report to the President, Washington, D.C.: U.S. Government Printing Office

Chandler, Alfred D. (1992). "Organizational Capabilities and the Economic History of the Industrial Enterprise,” Journal of Economic Perspectives, 6: 79-100.

Coase, Ronald H. (1937). “The Nature of the Firm,” Economica, New Series, 4: 386-405.

Cole, Arthur H. (1946). “An Approach to the Study of Entrepreneurship: A Tribute to Edwin F. Gay,” Journal of Economic History, 6: 1-15. 
Cole, Arthur H. (1949). "Entrepreneurship and Entrepreneurial History,” in Change and the Entrepreneur edited by the Research Center in Entrepreneurial History, Cambridge, MA: Harvard University Press.

Colombo, Massimo G. and Luca Grilli (2005). “Founders’ Human Capital and the Growth of New Technology-Based Firms: A Competence-Based View,” Research Policy, 34: 795-816.

Dasgupta, Partha and Paul A. David (1994). “Toward a New Economics of Science,” Research Policy, 23: 487-521.

Delmar, Frederic and Scott Shane (2002). "What Firm Founders Do: A Longitudinal Study of the Start-up Process," in Frontiers of Entrepreneurship Research 2002: Proceedings of the Twenty-Second Annual Entrepreneurship Research Conference. Babson College, Babson Park, MA.

Geuna, Aldo and Lionel J.J. Nesta (2006). "University Patenting and Its Effects on Academic Research: The Emerging European Evidence, Research Policy, 35: 790-807.

Hébert, Robert F. and Albert N. Link (1989). "In Search of the Meaning of Entrepreneurship," Small Business Economics, 1: 39-49.

Hébert, Robert F. and Albert N. Link (2006). “The Entrepreneur as Innovator,” Journal of Technology Transfer, 31: 589-97.

Hébert, Robert F. and Albert N. Link (2007). "Historical Perspectives on the Entrepreneur," Foundations and Trends in Entrepreneurship, 4: 1-164.

Hébert, Robert F. and Albert N. Link (forthcoming). A History of Entrepreneurship, London: Routledge.

Kane, Eileen (2006). “Patent Ineligibility: Maintaining a Scientific Public Domain,” St. John’s Law Review, 80: 519-558.

Langlois, Richard N. and Nicolai J. Foss (1999). "Capabilities and Governance: The Rebirth of production in the Theory of Economic Organization,” Kyklos, 52: 201-218.

Link, Albert N. and Jamie R. Link (forthcoming). Government as Entrepreneur, Oxford: Oxford University Press.

Link, Albert N. and Christopher J. Ruhm (forthcoming). "Bringing Science to Market: Commercializing from NIH SBIR Awards," Economics of Innovation and New Technology. Also published as NBER Working Paper 14057, June 2008. 
Link, Albert N. and Donald S. Siegel (2007). Innovation, Entrepreneurship, and Technological Change, Oxford: Oxford University Press.

Mohammed, Emir Aly Crowne (2008). "What is an Invention? A review of the Literature on Patentable Subject Matter," Richmond Journal of Law and Technology, XV: 1-36.

Penrose, Edith T. (1959). The Theory of the Growth of the Firm, New York: John Wiley \& Sons.

Porter, Michael E. (1980). Competitive Strategy: Techniques for Analyzing Industries and Competitors, New York: Free Press.

Porter, Michael E. (1985). Competitive Advantage: Creating and Sustaining Superior Performance. New York: Free Press.

Richardson, George B. (1972). “The Organsation of Industry,” Economic Journal, 82: 883-896. Roper, Stephen (1998). "Entrepreneurial Characteristics, Strategic Choice and Small Business Performance,” Small Business Economics, 11: 11-24.

Schumpeter, Joseph A. (1928). “The Instability of Capitalism,” Economic Journal, 38: 361-386.

Schumpeter, Joseph A. (1934). The Theory of Economic Development, translated by R. Opie from the $2^{\text {nd }}$ German edition [1926], Cambridge, MA: Harvard University Press.

Schumpeter, Joseph A. (1939). Business Cycles, New York: McGraw-Hill.

Shane, Scott (2003). General Theory of Entrepreneurship: The Individual-Opportunity Nexus, London: Edward Elgar.

Stern, Scott (2004). “Do Scientists pay to be Scientists?” Management Science, 50: 835-853.

Stinchcombe, Arthur L. (1965). "Social Structure and Organizations,” in Handbook of Organizations (edited by J. G. March), Chicago: Rand McNally \& Company.

Stokes, Donald E. (1997). Pasteur's Quadrant: Basic Science and Technological Innovation, Washington, D.C.: Brookings Institution Press.

Stuart, Toby E., Salih Zeki Ozdemir, and Waverly W. Ding (2007). "Vertical Alliance Networks: The Case of University-Biotechnology-Pharmaceutical Alliance Chains,” Research Policy, 36: 477-498.

Teece, David J. and Gary Pisano (1994). “The Dynamic Capabilities of Firms: An Introduction,” Industrial and Corporate Change, 3: 537-556.

Teece, David J., Gary Pisano, and Amy Shuen (1997). “Dynamic Capabilities and Strategic Management,” Strategic Management Journal, 18: 509-533. 
Wernerfelt, Birger. (1984). “A Resource Based View of the Firm,” Strategic Management Journal," 5: 171-180.

Wessner, Charles W. (2004). SBIR Program Diversity and Assessment Challenges, Washington, DC: National Academy Press.

Wessner, Charles W. (2008). An Assessment of the Small Business Innovation Research

Program, Washington, DC: National Academy Press. 